\title{
Giving more enhances your happiness: Evidence from Indonesia
}

\author{
Radikal Yuda Utama ${ }^{\text {a,* }}$, Herman Palani ${ }^{\mathrm{b}}$, Ahmad Zufar Robbani ${ }^{\mathrm{b}}$ \\ ${ }^{a}$ The Australian National University, Canberra ACT 2600, Australia \\ ${ }^{b}$ Center for Research in Islamic Economics and Business, Universitas Gadjah Mada, Yogyakarta 55281, Indonesia
}

Article history:

Received: 29 March 2021 / Received in revised form: 22 June 2021 / Accepted: 23 June 2021

\begin{abstract}
Previous studies revealed that consuming activities and spending money to meet needs can improve individuals' happiness. Our study showed that spending money, not for personal needs also has a big impact on individuals' well-being. We used 26,464 observations of $4^{\text {th }}$ and $5^{\text {th }}$ waves of the Indonesian Family Life Survey (IFLS) to predict the expenditures for non-personal needs (known as prosocial expenditure) on one's subjective well-being. The estimation result of the probit model showed that pro-social expenditure had a positive correlation with subjective well-being. On average, those who spend more on charity are happier than people who spend less. We also found that prosocial expenditure among Muslim and non-Muslim observations had different effects on happiness and life satisfaction.
\end{abstract}

Keywords: happiness; life satisfaction; prosocial expenditure; subjective well-being

\section{Introduction}

In a physiological concept, happiness is not always derived by receiving or consuming. Giving or helping other people can give happiness or satisfaction to someone who gives or helps. There are a number of research showing a positive correlation between giving others (in this context we call it as prosocial expenditure) on the happiness of the giver (Aknin et al., 2012; Choi \& Kim, 2011; Dunn et al., 2008; Lai et al., 2020; Miles et al., 2021; Chen et al., 2020; Gherghel et al., 2019). Some studies have opposite findings. The study from Dave Webb \& Janine Wong (2014) showed that prosocial spending (donation behavior) did not influence the happiness of the giver (Webb \& Wong, 2014). On top of that, Eisenberg and Miller (1987) stood moderately, their finding was unspecified and may be positive, negative, or both (Eisenberg \& Miller, 1987).

In Indonesia with the largest Muslim population in the world, Ziswaf is known as the largest component of charity funds (Perbawa \& Abdullah, 2016; UNDIP \& BAZNAS, 2018). Ziswaf itself is an abbreviation of Zakat, Infaq, Sadaqah and Waqf. Simply put, the various terms of charity above are part of the teachings in Islam. There are many institutions, organizations and platforms that raise philanthropic funds such as BAZNAS, LAZNAS, Indonesian Waqf Board, Dompet Dhuafa, Kitabisa.com, Aksi Cepat Tanggap, and others. To illustrate, the Islamic Development Bank discovered the potential for zakat in Indonesia of US\$ 16 billion (Rp217 trillion). In 2020, BAZNAS raised charity funds of 385.8 billion rupiahs, an increase of 30 percent from 296 billion rupiahs in 2019 (BAZNAS, 2021). Another example, in 2018

* Corresponding author. Tel.: +6289620688585

Email: radikal.utama@anu.edu.au

https://doi.org/10.21924/chss.1.1.2021.8
Kitabisa.com collected 472. These donations have funded 26,922 projects or campaigns (Online Giving Report, 2018). This fund helped many people in the field of education, health, culture, poverty alleviation, or venture capital.

In general, Muslim majority countries see the concept of giving, especially zakat, as something compulsory. This kind of charity is the third pillar of Islam. Every Muslim is obliged to pay zakat both zakat fitrah (yearly) and zakat maal (in terms of fulfilling the haul or nisab) (Junaidi \& Rizkiyah, 2013; Perbawa \& Abdullah, 2018). While the concept of giving in most of the non-Muslim countries are not based on religious compulsion. Hence, psychological experiences between them are incomparable.

According to the abovementioned points, our study attempted to seek the relation between pro-social expenditures on subjective well-being in Indonesia. Can it give happiness to the givers?

\subsection{Theoretical background}

At least three theories explain why the act of giving can promote happiness. The first theory is perfect altruism explaining that the determinant of donors' satisfaction is not influenced by how much contribution they have given (Andreoni, 1989). Instead, their satisfaction is determined by how many resources the recipients receive. Thereof, the donors would be indifferent about whether the recipients get the charity from themselves or other people. The implicit assumption here is the donors must know well-being of potential recipients to make them satisfied. Through this assumption, not all forms of donations can be analyzed in this theoretical framework since some forms of charity do not explicitly explain the well-being of the recipients. 
Put Zakat as the illustration in which zakat is donation issued by Muslims to fulfil their obligation, the minimum amount of zakat is determined by religious rules. To donate zakat, people have two scenarios. First, they can directly donate to those who need (people who are entitled to receive zakat). In this scenario, zakat can be analyzed through this framework. But sometimes people choose to donate their zakat through amil (the intermediaries with responsibilities to receive, manage and distribute zakat). In this second scenario, people potentially do not know the well-being of the recipient since they entrust amil for the distribution process. So, the satisfaction of the donors would be very difficult to be analyzed through Perfect Altruism theory. However, it can be accommodated by Warm Glow Theory.

Warm Glow Theory emerges as a criticism of altruism. This theory argues that factors, which influence the givers' satisfaction not limited by only one. Many factors may contribute and motivate people to donate such as prestige, respect, friendship, social pressure, guilt and other social and psychological objectives (Andreoni, 1989). In contrary to Perfect Altruism, this theory explains that donors give donations to receive internal satisfaction although their contribution may be completely anonymous (Andreoni, 1990). The utility of donors would be mostly determined by how many donations they can give. Therefore, they would prefer that donations come from themselves rather than from others.

Besides perfect altruism and warm glow theory, another theory, which explains why giving can promote happiness is the self-determination theory. This theory provides a framework for understanding why prosocial spending promotes happiness.

According to this theory, prosocial spending could lead to higher happiness if it satisfies three basic needs: relatedness, competence, and autonomy (Weinstein \& Ryan, 2010). Relatedness suggests that giving behavior can promote happiness if it could create a social connection between the giver and the recipients. One study found that individuals get more happiness from prosocial spending when donating allow to connect with other people (Aknin et al., 2013).

The need for competence explains that the individual will experience higher happiness if they could see the positive impact of a donation. Therefore, donating behavior could give a positive impact on happiness if the donors are offered a concrete promise such as "for every $\$ 100$ given, the donations will provide a vaccine to protect the child from malaria". Lastly, the need for autonomy state that people will get stronger happiness if they are given a choice where to give. Weinstein and Ryan (2010) showed that people would receive higher happiness when they donate more money away-but only if they had a choice about how much to give.

\subsection{Previous studies}

Some studies showed the impact of donations on donors' well-being. Aknin et al. (2013); Gherghel et al. (2019); Lai et al. (2020); Song et al. (2019) found a positive feedback looping between prosocial spending and happiness. It means that the higher happiness will increase the possibility of people to engage in pro-social spending. Other results showed that past prosocial spending led to a higher level of happiness. Another research showed a positive impact of charitable donations on psychological wellbeing. Choi, Kim, and Choi (2015) showed that people who give charity of more than $\$ 100$ monthly will have a greater psychological well-being than those who give only $\$ 100$ monthly. Another study also showed the positive impact of giving charity on the well-being of the donors in Korea (Kim et al., 2007). Other research showed that the effect of giving on happiness would depend on the donation method. For examples, Harbaugh et al. (2007) figured out that people would be happier when they freely gave to a local charity rather than they were forced to do so. Weinstein \& Ryan, (2010) founded that people would be happier when they had a choice about how much to give. These studies support an argument that the donation method also influences happiness.

The relatedness factor also plays a key role in the effect of donations on happiness. Aknin et al. (2011) found that individuals get higher happiness from the money they give if they spend money on close others rather than on acquaintances. Moreover, other studies revealed that people would be more happiness if they could see the positive impact of their donations (Aknin et al., 2013; Gherghel et al., 2019; Zhang et al., 2018). It signifies that the form of donations that give a concrete promise will lead to higher happiness.

Instead of positive impact, another study stated that there was no effect of prosocial spending on happiness. One study conducted in Singapore found that prosocial spending did not affect the subjective well-being of the donors (Webb \& Wong, 2014). Slightly similar, study of Falk \& Graeber (2020) found that prosocial expenditure significantly led to lower happiness in the long-run.

At the macro-level, Aknin et al. (2013) examined the association between prosocial spending and happiness in 136 countries. In most of the countries, there was a positive association between donating and happiness and this relationship was significant in most of the countries. Although the force of the relationship varied among countries, individuals in poor and rich countries reported more happiness if they experienced a pro-social spending (Aknin et al., 2013)

\section{Methodology}

\subsection{Data}

To explore a relationship between the concepts included in this study, we used secondary data from the Indonesian Family Life Survey (IFLS) wave 4 and 5 (Strauss, et al. 2018). IFLS is a longitudinal economic and health survey based on the sampling conducted in 1993 (IFLS wave 1) against households in 13 of 26 provinces in Indonesia at that time. This initial survey represented $83 \%$ of the population in Indonesia. IFLS 4 was held from the end of 2007 to early 2008 and had a total of 13,535 households. Of the total number of households, 44,103 individuals were able to gather information either through direct interviews or proxy. Meanwhile, IFLS 5 was held from the end of 2014 until the beginning of 2015 and had a total observation of 16,204 households. From these households, 50,148 individuals could gather information either through direct interviews or through proxy.

\subsection{Variable construction}

The novelty of the methodology lied in two new constructed variables: subjective well-being and prosocial expenditure. We managed IFLS data based on the dimension of religiosity and time. The religiosity dimension was separated into two, Muslim and non-Muslim samples. The separation was to compromise 
the expenditure characteristics of Muslim, since, in reality, Muslim must consider prosocial spending such as ziswaf as compulsory and forced obligation. Meanwhile, for non-Muslim samples, such obligation is voluntarily and not forced. Regarding the time dimension, we measured the perception of samples toward well-being using three-time frames: now, past 5 years, and next 5 years.

\subsection{Subjective well-being}

Five relevant questions of IFLS were used to represent subjective well-being. Each of those consisted of a question of life satisfaction, a question of life happiness, and 3 three questions of sub jective poverty. Those questions were the scale questions that were then made into dummy variables $(1=$ feel rich and $0=$ feel poor). All questions were obtained from book $3 \mathrm{~A}$ well-being section of IFLS. The first question related to life satisfaction is, "Reflect on your life as a whole. How satisfied are you with your current life? "With a response of 1 (very satisfied) to 5 (very dissatisfied). The researcher reversed this scale so that the larger the scale showed higher satisfaction. The second question related to happiness is, "Considering the current situation, do you feel that you are very happy, happy, unhappy, or very unhappy?" With a response of 1 (very happy) to 4 (very unhappy). The researcher also reversed this scale. The next three questions related to subjective poverty is, "If you imagine six levels, where the first level is the level of the poorest people and the sixth level is the richest, what condition do you have at this level?" with response 1 (the poorest) to 6 (the richest). This question was followed by 2 further questions asking about the situation for the past 5 years and the next 5 years.

\subsection{Prosocial expenditure}

Prosocial expenditure on the IFLS is household-level data obtained from book 1 section household consumption. We used this data to represent individual spending for charity, assuming the decision to donate or share in the household is affected by all household members (not only head of household). In IFLS we could not separate the type of charity so that the data showed a whole of charity whatever it was. This might be our data limitation since we could not investigate the detail of portion of Zakat, Infaq, Sadaqah, and Waqf. At the same time, one of our issues was to see the impact of charity (zakat) that Muslims are required to pay. Then, we took the prosocial expenditure data from wave 4 and wave 5 to generate a new variable, namely consistency for donation.

\subsection{Individual characteristics}

Some of the individual characteristics that researchers used as control variables included age, gender (dummy variable $1=$ male), education level, marital status (dummy variable $1=$ married), subjective health condition (scale 1-4), religiosity (scale 1-4), and ethnicity (dummy variable 1 = Javanese).

\subsection{Household characteristics}

The characteristics of the household used in this study were household expenditure for charity (prosocial expenditure), settlements (dummy variable $1=$ urban), and material welfare. Material welfare was constructed from per capita income obtained by summing all household income and divided by the number of household members. Household income was obtained from several books and sections in IFLS because the households had their sources of income.

\subsection{Equations}

In this research the used model is presented as follows:

S-- ${ }^{-}=a+\sum_{j=1}^{m} \beta_{j} C_{j h}+\sum_{k=1}^{n} \gamma_{k} X_{k i h}+\sum_{l=1}^{o} \gamma_{l} Y_{l h}+u_{i h}$

where $S$ is a measure of subjective well-being for individuals $i$ in household $h, C$ is a measure of spending donations, $X$ is a vector of individual characteristics, and $Y$ is a vector of household characteristics. The dependent variable $S$ was represented by 5 indicators (life satisfaction, happiness, and 3 indicators of subjective poverty), while variable $C$ was represented by prosocial spending (charity) on the household. There were several specific specifications for control variables. In the age variable, several previous studies found that there was a nonlinear relationship, specifically the parabolic relationship between age and subjective well-being (Dolan, et al., 2008) so that the age and age squared variables were used in this model.

The model was then estimated using the Ordinary Least Square (OLS) method. However, the use of this method could lead to biased results because the dependent variable in the model was a dummy variable. It requires a method to make a nonlinear relationship between dependent variables and independent variables. To get around this, we used a probit model to estimate the relationship between dependent and independent variables. This model can produce the probabilities of estimation. While the parameters of the estimation results cannot be read directly and estimated coefficients are parameters of the latent model (Spermann, 2009).

To read the parameters of probit estimation, this study used the marginal effect of probit estimation. The parameter of marginal effect is the effect of a unit of change of independent variable on probability (dependent variable), given all remained variables are constant. The marginal effect of an independent variable depends on the value of the variable itself. Therefore, there is an individual marginal effect for each observation (Spermann, 2009).

\section{Results and Discussion}

\subsection{Results}

The summary statistics of each variable provided in Appendix 1. The number of observations, mean, min, max, and standard deviation are informed in that table. By using IFLS 4 (certain variable) and 5 , it could obtain 26,464 people. The number of observations in each variable was not the same because of the missing data.

This study used a Pearson Correlation to identify the relationship between the dependent variables (see Table 1). The result showed a strong relationship between subjective poverties. Individuals who feel poor now are likely to feel poor five years ago and will feel poor for the next five years. A weak 
correlation occurred between indicators of life satisfaction and happiness with all three indicators of subjective poverty. This confirmed that people who feel poor are not necessarily dissatisfied and unhappy with their lives, and vice versa.

Table 1. Pearson Correlation among dependent variables

\begin{tabular}{lcccc}
\hline \multicolumn{1}{c}{ Variable } & $\begin{array}{c}\text { Poor_ } \\
\text { now }\end{array}$ & $\begin{array}{c}\text { Poor_ } \\
\text { 5ago }\end{array}$ & $\begin{array}{c}\text { Poor_ } \\
\text { 5next }\end{array}$ & $\begin{array}{c}\text { Life } \\
\text { Satisfactic }\end{array}$ \\
\hline Poor_5ago & $0.5214^{*}$ & & & \\
Poor_5next & $0.5820^{*}$ & $0.3333^{*}$ & & \\
Life Satisfaction & $0.2440^{*}$ & $0.1095^{*}$ & $0.1796^{*}$ & \\
Happiness & $0.2139^{*}$ & $0.0860^{*}$ & $0.1987^{*}$ & $0.3407^{*}$ \\
\hline
\end{tabular}

Note: * Significant correlation in alpha $5 \%$.

\subsubsection{Prosocial expenditure and subjective poverty}

Table 2. Probit model estimation between prosocial expenditure and subjective poverty

\begin{tabular}{lccc}
\hline & (All Sample) & (Muslim Sample) & (Non-Muslim Sample) \\
\hline Variables & Poor now & Poor now & Poor now \\
lnexpcharity & $0.0927 * * *$ & $0.102 * * *$ & $0.0484 * *$ \\
& $(0.00682)$ & $(0.00731)$ & $(0.0200)$ \\
& Poor_5next & Poor_5next & Poor_5next \\
lnexpcharity & $0.0791^{* * *}$ & $0.0885^{* * *}$ & $0.0418^{* *}$ \\
& $(0.00732)$ & $(0.00785)$ & $(0.0211)$ \\
& Poor_5ago & Poor_5ago & Poor_5ago \\
& & & \\
lnexpcharity & $0.0332 * * *$ & $0.0364 * * *$ & 0.0157 \\
& $(0.00732)$ & $(0.00785)$ & $(0.0211)$ \\
\hline
\end{tabular}

Robust standard errors in parentheses

$* * * \mathrm{p}<0.01, * * \mathrm{p}<0.05, * \mathrm{p}<0.1$

Note: The estimations do not inform control variables

The estimation results showed that prosocial expenditure had a positive effect on subjective poverty either in subjective poverty now, five years ago, or in the next five years. People who spend higher donations tend to feel not poor with their current conditions, five years ago, and the next five years (all samples and Muslim samples). For the estimation of nonMuslim samples, the effect of prosocial spending on subjective poverty five years ago was insignificant.

\subsubsection{Prosocial expenditure and happiness}

Table 3. Probit model estimation between prosocial expenditure and happiness

\begin{tabular}{cccc}
\hline Variables & $\begin{array}{c}\text { (All Sample) } \\
\text { Happiness }\end{array}$ & $\begin{array}{c}\text { (Muslim Sample) } \\
\text { Happiness }\end{array}$ & $\begin{array}{c}\text { (Non-Muslim Sample) } \\
\text { Happiness }\end{array}$ \\
\hline \multirow{3}{*}{ lnexpcharity } & $\begin{array}{c}0.0584 * * * \\
(0.0102)\end{array}$ & $\begin{array}{c}0.0708 * * * \\
(0.0113)\end{array}$ & 0.0105 \\
& $(0.010261)$ \\
\hline
\end{tabular}

Robust standard errors in parentheses

$* * * \mathrm{p}<0.01, * * \mathrm{p}<0.05, * \mathrm{p}<0.1$

Note: The estimations do not inform control variables

Subjective well-being on happiness indicator showed the same results as the subjective poverty indicator. Prosocial expenditure had a positive effect on individual happiness. The estimation result showed that the more the spending to donate, the happier the people will be (all observation). The same result occurred for Muslim. While non-Muslim showed no difference or insignificant effect on happiness. Noted here, the result showed a probability.
Prosocial expenditure and life satisfaction

Table 4. Probit model estimation between prosocial expenditure and life satisfaction

\begin{tabular}{|c|c|c|c|}
\hline \multirow{2}{*}{ Variables } & (All Sample) & $\begin{array}{l}\text { (Muslim } \\
\text { Sample) }\end{array}$ & $\begin{array}{c}\text { (Non-Muslim } \\
\text { Sample) }\end{array}$ \\
\hline & $\begin{array}{c}\text { Dummy } \\
\text { life satisfaction }\end{array}$ & $\begin{array}{c}\text { Dummy } \\
\text { life satisfaction }\end{array}$ & $\begin{array}{c}\text { Dummy } \\
\text { life satisfaction }\end{array}$ \\
\hline \multirow[t]{2}{*}{ lnexpcharity } & $0.0583 * * *$ & $0.0666^{* * * *}$ & 0.0204 \\
\hline & $(0.00642)$ & $(0.00691)$ & $(0.0185)$ \\
\hline
\end{tabular}

Robust standard errors in parentheses

$* * * \mathrm{p}<0.01, * * \mathrm{p}<0.05, * \mathrm{p}<0.1$

Note: The estimations do not inform control variables

In this estimation, we used two waves of prosocial expenditure (IFLS 4 and IFLS 5). Because we measured the consistency of donation time by time, it was relevant to measure life satisfaction throughout individuals' life. The estimation showed that the impact of prosocial expenditure on whole-life satisfaction was positive but not for non-Muslim samples. The estimation using all observation (Muslim and non-Muslim) and Muslims only showed a significant effect on life satisfaction. It signified the greater a person's expenses for donating, the greater the chance to get life satisfaction.

\subsubsection{Other variables and subjective well-being}

The estimation results showed that some control variables, both individual and household characteristics, significantly influenced subjective well-being. In all observations (Muslim and non-Muslim), income per capita, marital status, sex, age, education, and health consistently affected subjective wellbeing. While urban variable only had no effect on subjective poverty five years ago. People who leave in urban areas had a higher probability to get more welfare. Just like the urban variable, religiosity also just had no significant effect on subjective poverty five years ago.

Especially for the age variable, as mentioned in the literature review, the age variable had a nonlinear correlation to the dependent variable. This study found a similar finding as Dolan, et al. (2008) did. The age variable had a parabolic (Ushaped) correlation to subjective well-being.

\subsubsection{The issue of marginal effect}

The result of the marginal effect estimation is informed as follows:

Table 5. Marginal effect estimations of Prosocial Expenditure on Subjective Well-Being Indicators

\begin{tabular}{lcc}
\hline Subjective Well-Being Indicators & Estimated marginal effect & Effect \\
\hline Poor_Now & $0.0313^{* * *}$ & Positive \\
& $(0.00230)$ & \\
Poor_5Next & $0.0246^{* * *}$ & Positive \\
& $(0.00230)$ & \\
Poor_5Ago & $0.00881^{* * *}$ & Positive \\
& $(0.00194)$ & \\
Happiness & $0.00653^{* * *}$ & Positive \\
& $(0.00114)$ & \\
Life Satisfaction & $0.0230^{* * *}$ & Positive \\
\hline
\end{tabular}

Robust standard errors in parentheses

$* * * \mathrm{p}<0.01, * * \mathrm{p}<0.05, * \mathrm{p}<0.1$

Note: The estimations do not inform control variables

In this estimation, the result showed a positive significant effect between prosocial expenditure on all subjective well- 
being indicators. On average, if the average prosocial expenditure of all observation went up by an infinitesimal amount, the probability for people to feel enough (not feel poor) with their current condition rose by 3.12 percent. The effect of prosocial expenditure on subjective poverty next five years $(2,46 \%)$ and five years ago $(0,881 \%)$ was found smaller than its effect on the current condition. Interestingly, happiness variable and life satisfaction expected to be affected bigger than subjective poverty indicators even smaller. On average, if the average prosocial expenditure of all observation went up by an infinitesimal amount, the probability for people to feel happy rose by 0,653 percent. While the probability for people to feel satisfied with their life rose 0,0253 percent.

\subsection{Discussion}

The estimations showed a positive correlation between prosocial expenditures on subjective well-being (in 5 indicators). This study supported previous findings from Aknin, et al. (2012); Choi \& Kim (2011); Dunn, et al. (2008); Lai, et al. (2020); Miles, et al. (2021); Chen, et al. (2020); and Gherghel, et al. (2019). However, our research could not distinguish prosocial spending showing the well-being of recipients and not. The consequence is that our study could not conclude that all types of charity can increase happiness. The separation of prosocial spending between those who know the recipients' well-being and not, might lead to different results. The reason is those who can see the well-being of the recipient have more driving factors of happiness as explained by all theories mentioned (the perfect altruism theory, warm glow theory, and self-determination theory). While those who do not know the recipients' well-being only be explained by warm glow theory.

On top of that, some of our findings are considerably unique. First, our study showed that subjective poverty was closely related to prosocial behavior. Those who gave more tended to feel less poor regardless how much their income level. In this estimate, Muslim samples showed higher results than non-Muslim. Afterwards, besides feeling less poor, those who spend more on prosocial expenditure feel happier than those who spend less. This is the case for both a Muslim and a non-Muslim. Ultimately, despite this finding only relate to Muslim samples, people who donate more have a greater chance of feeling satisfaction to their whole life.

With regard to previous studies, which argued that the level of happiness of givers is higher if they know the level of wellbeing of the recipients (Aknin, et al., 2013; Gherghel, et al., 2019; Zhang, et al., 2018), some consequences need attention from intermediaries and the government, at least for three aspects as follows.

First, increasing transparency in the ziswaf distribution process. Transparency gives the givers an opportunity to see who receive the money they are spending. This transparency also includes documentation for each disbursement. The more specific the documentation, the greater the chance the giver has to see the welfare of the recipient, finally the greater the happiness the giver will feel.

Second, improving accountability for reports of money distributed. Accountability for distributed funds is not only conveyed to the government but also conveyed to donors. Accountability provides a space for givers to know the impact of their actions, while simultaneously providing opportunities for intermediaries to build trust and integrity with stakeholders.
Third, the government has to provide a guarantee for a conducive ecosystem charity. It means that it guarantees the values of transparency and accountability in the ziswaf's intermediaries, and allows the donors as an individual to safely donate their money. Through this ecosystem, equal distribution is expected to be achieved by reaching more people and not concentrated only on a few recipients.

\section{Conclusion}

Based on the explanation of the content and discussion, it can be concluded that there is a positive effect of prosocial expenditures on subjective well-being. On average, the greater the prosocial expenditure of an individual, the more likely they feel enough (not feel poor), happy, and satisfied with their life. The study also found that prosocial expenditures on nonMuslim samples did not significantly affect some subjective well-being indicators. The impact of prosocial spending on subjective poverty where both Muslims and non-Muslims have a significant effect regardless the impact on Muslim was higher than non-Muslim.

\section{References}

Aknin, L. B., Dunn, E. W., Helliwell, J. F., Biswas-Diener, R., Nyende, P., Barrington-Leigh, C. P., Burns, J., Kemeza, I., Ashton-James, C. E. \& Norton, M. I. (2013). Prosocial spending and well-being: Cross-cultural evidence for a psychological universal. Journal of Personality and Social Psychology.

Aknin, L. B., Dunn, E. W. \& Norton, M. I. (2012). Happiness Runs in a Circular Motion: Evidence for a Positive Feedback Loop between Prosocial Spending and Happiness. Journal of Happiness Studies.

Aknin, L. B., Sandstrom, G. M., Dunn, E. W. \& Norton, M. I. (2011). It's the recipient that counts: Spending money on strong social ties leads to greater happiness than spending on weak social ties. PLOS ONE.

Andreoni, J. (1989). Giving with Impure Altruism: Applications to Charity and Ricardian Equivalence. Journal of Political Economy.

Andreoni, J. (1990). Impure Altruism and Donations to Public Goods: A Theory of Warm-Glow Giving. The Economic Journal.

BAZNAS. (2021). During pandemic 2020, fund collecting of BAZNAS raise 30 percent. $1-8$

Chang, W. C. (2009). Social capital and subjective happiness in Taiwan. International Journal of Social Economics.

Chen, X., Tian, L. \& Huebner, E. S. (2020). Bidirectional Relations Between Subjective Well-Being in School and Prosocial Behavior Among Elementary School-Aged Children: A Longitudinal Study. Child and Youth Care Forum, 49(1), 77-95.

Choi, N. G. \& Kim, J. (2011). The effect of time volunteering and charitable donations in later life on psychological wellbeing. Ageing and Society.

Choi, N. G., Kim, J. \& Choi, N. G. (2015). The effect of time volunteering and charitable The effect of time volunteering and charitable donations in later life on psychological wellbeing. 2011, 590-610.

Dolan, P., Peasgood, T. \& White, M. (2008). Do we really know what makes us happy? A review of the economic literature on the factors associated with subjective well-being. Journal of Economic Psychology.

Dunn, E. W., Aknin, L. B. \& Norton, M. I. (2008). Spending money on others promotes happiness. Science.

Eisenberg, N. \& Miller, P. A. (1987). The Relation of Empathy to Prosocial and Related Behaviors. In Psychological Bulletin.

Falk, A. \& Graeber, T. (2020). Delayed negative effects of prosocial spending on happiness. Proceedings of the National Academy of Sciences of the 
United States of America, 117(12), 6463-6468.

Gherghel, C., Nastas, D., Hashimoto, T. \& Takai, J. (2019). The relationship between frequency of performing acts of kindness and subjective wellbeing: A mediation model in three cultures. Current Psychology.

Harbaugh, W. T., Mayr, U. \& Burghart, D. R. (2007). Neural responses to taxation and voluntary giving reveal motives for charitable donations. Science.

Junaidi, E. \& Rizkiyah, P. D. (2013). Does contract type influence the Zakat, Infaq and Shadaqah donation of Islamic Microfinance customers ? Case study of Baitul Maal Wat Tamwil. 8th Conference on Islamic Economics and Finance.

Kim, M. S. O., Kim, H. Y. E. W. O. N., Cha, K. H. O. \& Lim, J. (2007). What makes koreans happy?: exploration on the structure of happy life among korean adults. 265-286.

Lai, W., Yang, Z., Mao, Y., Zhang, Q., Chen, H. \& Ma, J. (2020). When do good deeds lead to good feelings? Eudaimonic orientation moderates the happiness benefits of prosocial behavior. International Journal of Environmental Research and Public Health, 17(11), 1-12.

Miles, A., Andiappan, M., Upenieks, L. \& Orfanidis, C. (2021). Using prosocial behavior to safeguard mental health and foster emotional well-being during the COVID-19 pandemic: A registered report protocol for a randomized trial. PLoS ONE, 16(1 January), 1-20.

Online Giving Report. (2018).
Perbawa, A. \& Abdullah, H. (2016). Determinant Factors of Awareness for Paying Zakat on Baznas, Indonesia. SSRN Electronic Journal.

Perbawa, A. \& Abdullah, H. (2018). Determinant Factors of Awareness for Paying Zakat on Baznas, Indonesia. SSRN Electronic Journal.

Song, J., Gu, C. \& Zuo, B. (2019). Effect of charitable behavior on life satisfaction: A parallel multivariable mediation model. Social Behavior and Personality, 47(3).

Spermann, A. (2009). The Probit Model: a Learning Module. University of Freiburg.

UNDIP \& BAZNAS. (2018). Unlocking The Potential of Zakat and Other Forms of Islamic Finance To Achieve the SGDs in IndonesiaNo Title. UNDIP and BAZNAS

Webb, D. \& Wong, J. (2014). Exploring Antecedents of Charitable Giving and Their Impact on Subjective Well-Being in Singapore. 65-87.

Weinstein, N. \& Ryan, R. M. (2010). When Helping Helps: Autonomous Motivation for Prosocial Behavior and Its Influence on Well-Being for the Helper and Recipient. Journal of Personality and Social Psychology.

Zhang, W., Chen, M., Xie, Y. \& Zhao, Z. (2018). Prosocial Spending and Subjective Well-Being: The Recipient Perspective. Journal of Happiness Studies, 19(8), 2267-2281.

\section{Appendix}

Table A1. Summary statistics

\begin{tabular}{|c|c|c|c|c|c|}
\hline $\begin{array}{l}\text { Variable } \\
\text { Subjective Well-being }\end{array}$ & Obs & Mean & Std. Dev. & Min & Max \\
\hline Subjective Poverty_now (dummy) & 26,361 & .2906187 & .4540565 & 0 & 1 \\
\hline Subjective Poverty_5ago (dummy) & 26,284 & .1867676 & .3897323 & 0 & 1 \\
\hline Subjective Poverty_5next (dummy) & 25,031 & .7326515 & .4425846 & 0 & 1 \\
\hline Hapiness (dummy) & 26,464 & .920269 & .2708813 & 0 & 1 \\
\hline Life Satisfaction (dummy) & 26,464 & .4404474 & .4964502 & 0 & 1 \\
\hline \multicolumn{6}{|l|}{ Prosocial Expenditure } \\
\hline expcharity_2014 & 26,417 & 2.058 .444 & 7.689 .681 & 0 & $5.00 \mathrm{e}+08$ \\
\hline expcharity_2007 & 21,144 & 1.215 .389 & 7.227.514 & 0 & $1.00 \mathrm{e}+08$ \\
\hline In Expcharity_2014 & 25,828 & 1.352 .002 & 1.306 .229 & 6.907 .755 & 2.003.012 \\
\hline ln Expcharity_2007 & 19,181 & 1.251 .344 & 1.439 .342 & 6.907 .755 & 1.842 .068 \\
\hline \multicolumn{6}{|l|}{ Individual Characteristics } \\
\hline Married (dummy) & 26,464 & .7339404 & .4419041 & 0 & 1 \\
\hline Religion (dummy) & 26,464 & .9004308 & .2994304 & 0 & 1 \\
\hline Ethnic (dummy) & 26,464 & .4449063 & .4969648 & 0 & 1 \\
\hline Male (dummy) & 26,464 & .4745314 & .4993604 & 0 & 1 \\
\hline Age & 26,464 & 368.244 & 1.425 .935 & 14 & 101 \\
\hline Agesquared & 26,464 & 1.559 .358 & 1.197.039 & 196 & 10201 \\
\hline Educ & 26,464 & 9.191 .846 & 4.191 .794 & 0 & 22 \\
\hline Religiosity (scale 1-4) & 26,464 & 2.894 .725 & .6868071 & 1 & 4 \\
\hline Health (scale 1-4) & 26,464 & 297.472 & .6520742 & 1 & 4 \\
\hline \multicolumn{6}{|l|}{ Household Characteristics } \\
\hline Income Per Capita & 26,464 & 8.288 .301 & $3.13 e+07$ & 2.727 .273 & $3.00 \mathrm{e}+09$ \\
\hline In Income Per Capita & 26,464 & 151.621 & 1.356 .652 & 3.305 .887 & 2.182 .188 \\
\hline Urban (dummy) & 26,464 & .6306681 & .482633 & 0 & 1 \\
\hline
\end{tabular}

Table A2. Probit model estimation: determinants of the current subjective poverty

\begin{tabular}{lccc}
\hline Variables & $\begin{array}{c}\text { (All Sample) } \\
\text { Dummysubjective } \\
\text { poverty_now }\end{array}$ & $\begin{array}{c}\text { (Muslim Sample) } \\
\text { Dummysubjective } \\
\text { poverty_now }\end{array}$ & $\begin{array}{c}\text { (Non-Muslim Sample) } \\
\text { Dummysubjective } \\
\text { poverty_now }\end{array}$ \\
\hline lnexpcharity & $0.0927 * * *$ & $0.102 * * *$ & $(0.00731)$ \\
lnincomeperkapita & $(0.00682)$ & $0.103 * * *$ & $(0.0200)$ \\
& $0.102 * * *$ & $(0.00795)$ & $0.0842 * * *$
\end{tabular}


Table A2 "continued". Probit model estimation: determinants of the current subjective poverty

\begin{tabular}{|c|c|c|c|}
\hline Variables & $\begin{array}{c}\text { (All Sample) } \\
\text { Dummysubjective } \\
\text { poverty_now }\end{array}$ & $\begin{array}{c}\text { (Muslim Sample) } \\
\text { Dummysubjective } \\
\text { poverty_now }\end{array}$ & $\begin{array}{c}\text { (Non-Muslim Sample) } \\
\text { Dummysubjective } \\
\text { poverty_now }\end{array}$ \\
\hline married & $\begin{array}{c}-0.0785 * * * \\
(0.0231)\end{array}$ & $\begin{array}{c}-0.0932 * * * \\
(0.0243)\end{array}$ & $\begin{array}{c}0.0690 \\
(0.0747)\end{array}$ \\
\hline religion & $\begin{array}{c}0.236^{* * * *} \\
(0.0309)\end{array}$ & & \\
\hline ethnic & $\begin{array}{c}0.0155 \\
(0.0175)\end{array}$ & $\begin{array}{l}-0.00528 \\
(0.0180)\end{array}$ & $\begin{array}{c}0.301 * * * \\
(0.0772)\end{array}$ \\
\hline male & $\begin{array}{c}-0.278 * * * \\
(0.0172)\end{array}$ & $\begin{array}{c}-0.278 * * * \\
(0.0182)\end{array}$ & $\begin{array}{c}-0.256^{* * * *} \\
(0.0557)\end{array}$ \\
\hline age & $\begin{array}{c}-0.0272 * * * \\
(0.00341)\end{array}$ & $\begin{array}{c}-0.0265 * * * \\
(0.00360)\end{array}$ & $\begin{array}{c}-0.0302 * * * \\
(0.0108)\end{array}$ \\
\hline agesquared & $\begin{array}{c}0.000357 * * * \\
(3.99 \mathrm{e}-05)\end{array}$ & $\begin{array}{c}0.000350 * * * \\
(4.23 \mathrm{e}-05)\end{array}$ & $\begin{array}{c}0.000366 * * * \\
(0.000122)\end{array}$ \\
\hline educ & $\begin{array}{l}0.0471 * * * \\
(0.00244)\end{array}$ & $\begin{array}{c}0.0476 * * * \\
(0.00258)\end{array}$ & $\begin{array}{c}0.0335 * * * \\
(0.00769)\end{array}$ \\
\hline religiosity & $\begin{array}{c}0.154 * * * \\
(0.0132)\end{array}$ & $\begin{array}{c}0.159 * * * \\
(0.0139)\end{array}$ & $\begin{array}{c}0.125 * * * \\
(0.0444)\end{array}$ \\
\hline health & $\begin{array}{c}0.140 * * * \\
(0.0136)\end{array}$ & $\begin{array}{c}0.138 * * * \\
(0.0142)\end{array}$ & $\begin{array}{c}0.164 * * * \\
(0.0467)\end{array}$ \\
\hline urban & $\begin{array}{c}-0.000740 \\
(0.0187)\end{array}$ & $\begin{array}{l}-0.0122 \\
(0.0196)\end{array}$ & $\begin{array}{c}0.0768 \\
(0.0610)\end{array}$ \\
\hline Constant & $\begin{array}{c}-4.263^{* * * *} \\
(0.157)\end{array}$ & $\begin{array}{c}-4.172 * * * \\
(0.159)\end{array}$ & $\begin{array}{c}-3.306^{* * *} * \\
(0.459)\end{array}$ \\
\hline Observations & 25,731 & 23,250 & 2,481 \\
\hline
\end{tabular}

Robust standard errors in parentheses

$* * * \mathrm{p}<0.01, * * \mathrm{p}<0.05, * \mathrm{p}<0.1$

Table A3. Probit model estimation: determinants of subjective poverty on next five years

\begin{tabular}{|c|c|c|c|}
\hline Variables & $\begin{array}{c}\text { (All Sample) } \\
\text { Dummysubjective } \\
\text { poverty_5next }\end{array}$ & $\begin{array}{c}\text { (Muslim Sample) } \\
\text { Dummysubjective } \\
\text { poverty_5next }\end{array}$ & $\begin{array}{c}\text { (Non-Muslim Sample) } \\
\text { Dummysubjective } \\
\text { poverty_5next }\end{array}$ \\
\hline lnexpcharity & $\begin{array}{c}0.0791 * * * \\
(0.00742)\end{array}$ & $\begin{array}{c}0.0885 * * * \\
(0.00808)\end{array}$ & $\begin{array}{c}0.0418 * * \\
(0.0202)\end{array}$ \\
\hline Inincomepercapita & $\begin{array}{c}0.0873 * * * \\
(0.00737)\end{array}$ & $\begin{array}{c}0.0928 * * * \\
(0.00783)\end{array}$ & $\begin{array}{c}0.0466^{* *} \\
(0.0218)\end{array}$ \\
\hline married & $\begin{array}{c}-0.0549 * * \\
(0.0257)\end{array}$ & $\begin{array}{c}-0.0584 * * \\
(0.0272)\end{array}$ & $\begin{array}{l}-0.0334 \\
(0.0793)\end{array}$ \\
\hline religion & $\begin{array}{c}0.298 * * * \\
(0.0321)\end{array}$ & & \\
\hline ethnic & $\begin{array}{c}0.0438 * * \\
(0.0188)\end{array}$ & $\begin{array}{c}0.0263 \\
(0.0196)\end{array}$ & $\begin{array}{c}0.275 * * * \\
(0.0847)\end{array}$ \\
\hline male & $\begin{array}{c}-0.211 * * * \\
(0.0185)\end{array}$ & $\begin{array}{c}-0.212 * * * \\
(0.0196)\end{array}$ & $\begin{array}{c}-0.182 * * * \\
(0.0574)\end{array}$ \\
\hline age & $\begin{array}{c}-0.0296 * * * \\
(0.00375)\end{array}$ & $\begin{array}{c}-0.0310 * * * \\
(0.00399)\end{array}$ & $\begin{array}{l}-0.0154 \\
(0.0113)\end{array}$ \\
\hline agesquared & $\begin{array}{c}0.000139 * * * \\
(4.31 \mathrm{e}-05)\end{array}$ & $\begin{array}{c}0.000152 * * * \\
(4.59 \mathrm{e}-05)\end{array}$ & $\begin{array}{c}-1.99 \mathrm{e}-05 \\
(0.000128)\end{array}$ \\
\hline educ & $\begin{array}{c}0.0629 * * * \\
(0.00252)\end{array}$ & $\begin{array}{c}0.0630 * * * \\
(0.00268)\end{array}$ & $\begin{array}{l}0.0544 * * * \\
(0.00755)\end{array}$ \\
\hline religiosity & $\begin{array}{c}0.0573 * * * \\
(0.0140)\end{array}$ & $\begin{array}{c}0.0662^{* * * *} \\
(0.0147)\end{array}$ & $\begin{array}{c}-0.000635 \\
(0.0463)\end{array}$ \\
\hline health & $\begin{array}{c}0.108 * * * \\
(0.0141)\end{array}$ & $\begin{array}{c}0.107 * * * \\
(0.0149)\end{array}$ & $\begin{array}{c}0.123 * * * \\
(0.0460)\end{array}$ \\
\hline urban & $\begin{array}{c}0.0611 * * * \\
(0.0198)\end{array}$ & $\begin{array}{c}0.0448 * * \\
(0.0210)\end{array}$ & $\begin{array}{c}0.187 * * * \\
(0.0618)\end{array}$ \\
\hline Constant & $\begin{array}{c}-2.078 * * * \\
(0.161)\end{array}$ & $\begin{array}{c}-1.958^{* * * *} \\
(0.166)\end{array}$ & $\begin{array}{c}-1.121 * * \\
(0.438)\end{array}$ \\
\hline Observations & 24,443 & 22,125 & 2,318 \\
\hline
\end{tabular}

Robust standard errors in parentheses

$* * * \mathrm{p}<0.01, * * \mathrm{p}<0.05, * \mathrm{p}<0.1$

Table A4. Probit model estimation: determinants of subjective poverty on five years ago

\begin{tabular}{|c|c|c|c|}
\hline Variables & $\begin{array}{c}\text { (All Sample) } \\
\text { Dummysubjective } \\
\text { poverty_5ago }\end{array}$ & $\begin{array}{c}\text { (Muslim Sample) } \\
\text { Dummysubjective } \\
\text { poverty_5ago }\end{array}$ & $\begin{array}{c}\text { (Non-Muslim Sample) } \\
\text { Dummysubjective } \\
\text { poverty_5ago }\end{array}$ \\
\hline lnexpcharity & $\begin{array}{c}0.0332 * * * \\
(0.00732)\end{array}$ & $\begin{array}{c}0.0364 * * * \\
(0.00785)\end{array}$ & $\begin{array}{c}0.0157 \\
(0.0211)\end{array}$ \\
\hline
\end{tabular}


Table A4 "continued". Probit model estimation: determinants of subjective poverty on five years ago

\begin{tabular}{|c|c|c|c|}
\hline Variables & $\begin{array}{c}\text { (All Sample) } \\
\text { Dummysubjective } \\
\text { poverty_5ago }\end{array}$ & $\begin{array}{c}\text { (Muslim Sample) } \\
\text { Dummysubjective } \\
\text { poverty_5ago }\end{array}$ & $\begin{array}{c}\text { (Non-Muslim Sample) } \\
\text { Dummysubjective } \\
\text { poverty_5ago }\end{array}$ \\
\hline Inincomepercapita & $\begin{array}{c}0.0128 * \\
(0.00758)\end{array}$ & $\begin{array}{c}0.00991 \\
(0.00797)\end{array}$ & $\begin{array}{c}0.0322 \\
(0.0247)\end{array}$ \\
\hline married & $\begin{array}{c}-0.104 * * * \\
(0.0247)\end{array}$ & $\begin{array}{c}-0.0976 * * * \\
(0.0259)\end{array}$ & $\begin{array}{c}-0.129 \\
(0.0803)\end{array}$ \\
\hline religion & $\begin{array}{c}0.145^{* * * *} \\
(0.0332)\end{array}$ & & \\
\hline ethnic & $\begin{array}{c}-0.0561 * * * \\
(0.0189)\end{array}$ & $\begin{array}{c}-0.0630 * * * \\
(0.0195)\end{array}$ & $\begin{array}{c}0.0352 \\
(0.0858)\end{array}$ \\
\hline male & $\begin{array}{c}-0.121 * * * \\
(0.0186)\end{array}$ & $\begin{array}{c}-0.113^{* * *} \\
(0.0196)\end{array}$ & $\begin{array}{c}-0.182 * * * \\
(0.0610)\end{array}$ \\
\hline age & $\begin{array}{c}-0.0357 * * * \\
(0.00364)\end{array}$ & $\begin{array}{c}-0.0367 * * * \\
(0.00383)\end{array}$ & $\begin{array}{c}-0.0313 * * * \\
(0.0116)\end{array}$ \\
\hline agesquared & $\begin{array}{c}0.000503 * * * \\
(4.20 \mathrm{e}-05)\end{array}$ & $\begin{array}{c}0.000519 * * * \\
(4.43 \mathrm{e}-05)\end{array}$ & $\begin{array}{c}0.000403 * * * \\
(0.000131)\end{array}$ \\
\hline educ & $\begin{array}{c}0.0283 * * * \\
(0.00263)\end{array}$ & $\begin{array}{c}0.0289 * * * \\
(0.00277)\end{array}$ & $\begin{array}{l}0.0201 * * \\
(0.00854)\end{array}$ \\
\hline religiosity & $\begin{array}{l}0.00941 \\
(0.0141)\end{array}$ & $\begin{array}{c}0.0150 \\
(0.0149)\end{array}$ & $\begin{array}{l}-0.0505 \\
(0.0471)\end{array}$ \\
\hline health & $\begin{array}{c}0.0390 * * * \\
(0.0146)\end{array}$ & $\begin{array}{l}0.0299 * \\
(0.0153)\end{array}$ & $\begin{array}{l}0.123 * * \\
(0.0515)\end{array}$ \\
\hline urban & $\begin{array}{c}0.0617 * * * \\
(0.0202)\end{array}$ & $\begin{array}{c}0.0549 * * * \\
(0.0212)\end{array}$ & $\begin{array}{c}0.113^{*} \\
(0.0679)\end{array}$ \\
\hline Constant & $\begin{array}{c}-1.434 * * * \\
(0.161)\end{array}$ & $\begin{array}{c}-1.272 * * * \\
(0.163)\end{array}$ & $\begin{array}{c}-1.458 * * * \\
(0.473)\end{array}$ \\
\hline Observations & 25,657 & 23,184 & 2,473 \\
\hline
\end{tabular}

Robust standard errors in parentheses

$* * * \mathrm{p}<0.01, * * \mathrm{p}<0.05, * \mathrm{p}<0.1$

Table A5. Probit model estimation: determinants of happiness

\begin{tabular}{|c|c|c|c|}
\hline Variables & $\begin{array}{c}\text { (All Sample) } \\
\text { dummyhappiness }\end{array}$ & $\begin{array}{l}\text { (Muslim Sample) } \\
\text { dummyhappiness }\end{array}$ & $\begin{array}{c}\text { (Non-Muslim Sample) } \\
\text { dummyhappiness }\end{array}$ \\
\hline lnexpcharity & $\begin{array}{c}0.0584 * * * \\
(0.0102)\end{array}$ & $\begin{array}{c}0.0708 * * * \\
(0.0113)\end{array}$ & $\begin{array}{c}0.0105 \\
(0.0261)\end{array}$ \\
\hline Inincomepercapita & $\begin{array}{l}0.116 * * * \\
(0.00913)\end{array}$ & $\begin{array}{l}0.117 * * * \\
(0.00988)\end{array}$ & $\begin{array}{l}0.109 * * * \\
(0.0244)\end{array}$ \\
\hline married & $\begin{array}{l}0.458 * * * \\
(0.0321)\end{array}$ & $\begin{array}{l}0.472 * * * \\
(0.0343)\end{array}$ & $\begin{array}{l}0.346 * * * \\
(0.0937)\end{array}$ \\
\hline religion & $\begin{array}{c}0.344 * * * \\
(0.0406)\end{array}$ & & \\
\hline ethnic & $\begin{array}{l}-0.0318 \\
(0.0256)\end{array}$ & $\begin{array}{c}-0.0596 * * \\
(0.0269)\end{array}$ & $\begin{array}{l}0.397 * * * \\
(0.127)\end{array}$ \\
\hline male & $\begin{array}{c}-0.131 * * * \\
(0.0251)\end{array}$ & $\begin{array}{c}-0.136^{* * * *} \\
(0.0267)\end{array}$ & $\begin{array}{l}-0.0786 \\
(0.0741)\end{array}$ \\
\hline age & $\begin{array}{c}-0.0494 * * * \\
(0.00491)\end{array}$ & $\begin{array}{c}-0.0508 * * * \\
(0.00527)\end{array}$ & $\begin{array}{c}-0.0357 * * \\
(0.0141)\end{array}$ \\
\hline agesquared & $\begin{array}{c}0.000463 * * * \\
(5.56 \mathrm{e}-05)\end{array}$ & $\begin{array}{c}0.000479 * * * \\
(5.98 \mathrm{e}-05)\end{array}$ & $\begin{array}{l}0.000296 * \\
(0.000156)\end{array}$ \\
\hline educ & $\begin{array}{l}0.0534 * * * \\
(0.00341)\end{array}$ & $\begin{array}{l}0.0543 * * * \\
(0.00369)\end{array}$ & $\begin{array}{l}0.0392 * * * \\
(0.00939)\end{array}$ \\
\hline religiosity & $\begin{array}{l}0.164 * * * \\
(0.0189)\end{array}$ & $\begin{array}{l}0.169 * * * \\
(0.0201)\end{array}$ & $\begin{array}{l}0.143 * * \\
(0.0588)\end{array}$ \\
\hline health & $\begin{array}{l}0.345 * * * \\
(0.0202)\end{array}$ & $\begin{array}{l}0.336 * * * \\
(0.0214)\end{array}$ & $\begin{array}{l}0.436 * * * \\
(0.0624)\end{array}$ \\
\hline urban & $\begin{array}{c}-0.0769 * * * \\
(0.0269)\end{array}$ & $\begin{array}{c}-0.0820 * * * \\
(0.0286)\end{array}$ & $\begin{array}{l}-0.0606 \\
(0.0785)\end{array}$ \\
\hline Constant & $\begin{array}{c}-2.369 * * * \\
(0.211)\end{array}$ & $\begin{array}{c}-2.160 * * * \\
(0.222)\end{array}$ & $\begin{array}{c}-1.897 * * * \\
(0.530)\end{array}$ \\
\hline Observations & 25,828 & 23,341 & 2,487 \\
\hline
\end{tabular}

Robust standard errors in parentheses

$* * * \mathrm{p}<0.01, * * \mathrm{p}<0.05, * \mathrm{p}<0.1$ 
Table A6. Probit model estimation: determinants of life satisfaction

\begin{tabular}{|c|c|c|c|}
\hline Variables & $\begin{array}{c}\text { (All Sample) } \\
\text { dummylifesatisfaction }\end{array}$ & $\begin{array}{c}\text { (Muslim Sample) } \\
\text { dummylifesatisfaction }\end{array}$ & $\begin{array}{l}\text { (Non-Muslim Sample) } \\
\text { dummylifesatisfaction }\end{array}$ \\
\hline lnexpcharity & $\begin{array}{c}0.0583 * * * \\
(0.00642)\end{array}$ & $\begin{array}{c}0.0666 * * * \\
(0.00691)\end{array}$ & $\begin{array}{c}0.0204 \\
(0.0185)\end{array}$ \\
\hline Inincomepercapita & $\begin{array}{c}0.0575 * * * \\
(0.00672)\end{array}$ & $\begin{array}{c}0.0593 * * * \\
(0.00712)\end{array}$ & $\begin{array}{l}0.0365^{*} \\
(0.0206)\end{array}$ \\
\hline married & $\begin{array}{c}0.107 * * * \\
(0.0222)\end{array}$ & $\begin{array}{c}0.102 * * * \\
(0.0234)\end{array}$ & $\begin{array}{l}0.179 * * \\
(0.0720)\end{array}$ \\
\hline religion & $\begin{array}{r}0.264 * * * \\
(0.0287)\end{array}$ & & \\
\hline ethnic & $\begin{array}{l}-0.0250 \\
(0.0165)\end{array}$ & $\begin{array}{c}-0.0416^{* * *} \\
(0.0170)\end{array}$ & $\begin{array}{c}0.202 * * * \\
(0.0758)\end{array}$ \\
\hline male & $\begin{array}{c}-0.114 * * * \\
(0.0162)\end{array}$ & $\begin{array}{c}-0.110 * * * \\
(0.0170)\end{array}$ & $\begin{array}{c}-0.140 * * * \\
(0.0525)\end{array}$ \\
\hline age & $\begin{array}{c}-0.0375 * * * \\
(0.00325)\end{array}$ & $\begin{array}{c}-0.0358 * * * \\
(0.00343)\end{array}$ & $\begin{array}{c}-0.0544 * * * \\
(0.0104)\end{array}$ \\
\hline agesquared & $\begin{array}{c}0.000380 * * * \\
(3.80 \mathrm{e}-05)\end{array}$ & $\begin{array}{c}0.000361 * * * \\
(4.02 \mathrm{e}-05)\end{array}$ & $\begin{array}{c}0.000546 * * * \\
(0.000119)\end{array}$ \\
\hline educ & $\begin{array}{c}0.00465 * * \\
(0.00224)\end{array}$ & $\begin{array}{c}0.00329 \\
(0.00237)\end{array}$ & $\begin{array}{c}0.00992 \\
(0.00705)\end{array}$ \\
\hline religiosity & $\begin{array}{c}0.285 * * * \\
(0.0125)\end{array}$ & $\begin{array}{c}0.288^{* * * *} \\
(0.0131)\end{array}$ & $\begin{array}{c}0.278 * * * \\
(0.0429)\end{array}$ \\
\hline health & $\begin{array}{l}0.249 * * * \\
(0.0127)\end{array}$ & $\begin{array}{c}0.244 * * * \\
(0.0133)\end{array}$ & $\begin{array}{c}0.309 * * * \\
(0.0436)\end{array}$ \\
\hline urban & $\begin{array}{c}0.0604 * * * \\
(0.0175)\end{array}$ & $\begin{array}{c}0.0597 * * * \\
(0.0184)\end{array}$ & $\begin{array}{c}0.0435 \\
(0.0573)\end{array}$ \\
\hline religion & & - & - \\
\hline Constant & $\begin{array}{l}-2.926 * * * \\
(0.144)\end{array}$ & $\begin{array}{c}-2.802 * * * \\
(0.146)\end{array}$ & $\begin{array}{c}-1.972 * * * \\
(0.417)\end{array}$ \\
\hline Observations & 25,828 & 23,341 & 2,487 \\
\hline
\end{tabular}

Robust standard errors in parentheses $* * * \mathrm{p}<0.01, * * \mathrm{p}<0.05, * \mathrm{p}<0.1$

Table A7. Marginal effect estimation: determinants of current subjective poverty

\begin{tabular}{|c|c|c|c|}
\hline Variables & $\begin{array}{c}\text { (All Sample) } \\
\text { Dummysubjective } \\
\text { poverty_now } \\
\text { (marginal effect) dydx }\end{array}$ & $\begin{array}{c}\text { (Muslim Sample) } \\
\text { Dummysubjective } \\
\text { poverty_now } \\
\text { (marginal effect) dydx }\end{array}$ & $\begin{array}{c}\text { (Non-Muslim Sample) } \\
\text { Dummysubjective } \\
\text { poverty_now } \\
\text { (marginal effect) dydx }\end{array}$ \\
\hline lnexpcharity & $\begin{array}{c}0.0313 * * * \\
(0.00230)\end{array}$ & $\begin{array}{c}0.0345 * * * \\
(0.00247)\end{array}$ & $\begin{array}{l}0.0158 * * \\
(0.00653)\end{array}$ \\
\hline lnincomepercapita & $\begin{array}{c}0.0343 * * * \\
(0.00253)\end{array}$ & $\begin{array}{c}0.0350 * * * \\
(0.00268)\end{array}$ & $\begin{array}{c}0.0275 * * * \\
(0.00776)\end{array}$ \\
\hline married & $\begin{array}{c}-0.0267 * * * \\
(0.00793)\end{array}$ & $\begin{array}{c}-0.0319 * * * \\
(0.00841)\end{array}$ & $\begin{array}{c}0.0223 \\
(0.0239)\end{array}$ \\
\hline religion & $\begin{array}{c}0.0750 * * * \\
(0.00913)\end{array}$ & & \\
\hline ethnic & $\begin{array}{c}0.00524 \\
(0.00591)\end{array}$ & $\begin{array}{l}-0.00178 \\
(0.00610)\end{array}$ & $\begin{array}{c}0.104 * * * \\
(0.0280)\end{array}$ \\
\hline male & $\begin{array}{c}-0.0929 * * * \\
(0.00572)\end{array}$ & $\begin{array}{c}-0.0934 * * * \\
(0.00604)\end{array}$ & $\begin{array}{c}-0.0832 * * * \\
(0.0180)\end{array}$ \\
\hline age & $\begin{array}{c}-0.00916 * * * \\
(0.00115)\end{array}$ & $\begin{array}{c}-0.00897 * * * \\
(0.00122)\end{array}$ & $\begin{array}{c}-0.00985^{* * *} * \\
(0.00351)\end{array}$ \\
\hline agesquared & $\begin{array}{c}0.000120 \text { *** } \\
(1.34 \mathrm{e}-05)\end{array}$ & $\begin{array}{c}0.000118 * * * \\
(1.43 \mathrm{e}-05)\end{array}$ & $\begin{array}{c}0.000119 * * * \\
(3.99 \mathrm{e}-05)\end{array}$ \\
\hline educ & $\begin{array}{l}0.0159 * * * \\
(0.000820)\end{array}$ & $\begin{array}{l}0.0161 * * * \\
(0.000870)\end{array}$ & $\begin{array}{c}0.0109 * * * \\
(0.00250)\end{array}$ \\
\hline religiosity & $\begin{array}{c}0.0519 * * * \\
(0.00445)\end{array}$ & $\begin{array}{c}0.0537 * * * \\
(0.00470)\end{array}$ & $\begin{array}{c}0.0409 * * * \\
(0.0145)\end{array}$ \\
\hline health & $\begin{array}{c}0.0471 * * * \\
(0.00458)\end{array}$ & $\begin{array}{c}0.0465 * * * \\
(0.00481)\end{array}$ & $\begin{array}{c}0.0536 * * * \\
(0.0152)\end{array}$ \\
\hline urban & $\begin{array}{l}-0.000250 \\
(0.00629)\end{array}$ & $\begin{array}{l}-0.00414 \\
(0.00665)\end{array}$ & $\begin{array}{c}0.0249 \\
(0.0197)\end{array}$ \\
\hline Observations & 25,731 & 23,250 & 2,481 \\
\hline
\end{tabular}

Robust standard errors in parentheses $* * * \mathrm{p}<0.01, * * \mathrm{p}<0.05, * \mathrm{p}<0.1$ 
Table A8. Marginal Effect Estimation: Determinants of Subjective Poverty Next Five Years

\begin{tabular}{|c|c|c|c|}
\hline \multirow{3}{*}{ Variables } & (All Sample) & (Muslim Sample) & (Non-Muslim Sample) \\
\hline & $\begin{array}{c}\text { Dummysubjective } \\
\text { poverty_5next }\end{array}$ & $\begin{array}{c}\text { Dummysubjective } \\
\text { poverty_5next }\end{array}$ & $\begin{array}{c}\text { Dummysubjective } \\
\text { poverty_5next }\end{array}$ \\
\hline & (marginal effect) dydx & (marginal effect) dydx & (marginal effect) dydx \\
\hline \multirow[t]{2}{*}{ lnexpcharity } & $0.0246 * * *$ & $0.0272 * * *$ & $0.0144 * *$ \\
\hline & $(0.00230)$ & $(0.00247)$ & $(0.00698)$ \\
\hline \multirow[t]{2}{*}{ Inincomepercapita } & $0.0272 * * *$ & $0.0285 * * *$ & $0.0161 * *$ \\
\hline & $(0.00229)$ & $(0.00240)$ & $(0.00753)$ \\
\hline \multirow[t]{2}{*}{ married } & $-0.0169 * *$ & $-0.0177 * *$ & -0.0115 \\
\hline & $(0.00784)$ & $(0.00818)$ & $(0.0272)$ \\
\hline \multirow[t]{2}{*}{ religion } & $0.0999 * * *$ & & \\
\hline & $(0.0115)$ & & \\
\hline \multirow[t]{2}{*}{ ethnic } & $0.0136^{* *}$ & 0.00807 & $0.0897 * * *$ \\
\hline & $(0.00583)$ & $(0.00599)$ & $(0.0259)$ \\
\hline \multirow[t]{2}{*}{ male } & $-0.0658 * * *$ & $-0.0653 * * *$ & $-0.0630 * * *$ \\
\hline & $(0.00577)$ & $(0.00603)$ & $(0.0198)$ \\
\hline \multirow{2}{*}{ age } & $-0.00921 * * *$ & $-0.00951 * * *$ & -0.00531 \\
\hline & $(0.00116)$ & $(0.00122)$ & $(0.00390)$ \\
\hline \multirow[t]{2}{*}{ agesquared } & $4.31 \mathrm{e}-05^{* * *}$ & $4.65 \mathrm{e}-05 * * *$ & $-6.87 e-06$ \\
\hline & $(1.34 \mathrm{e}-05)$ & $(1.41 \mathrm{e}-05)$ & $(4.41 \mathrm{e}-05)$ \\
\hline \multirow[t]{2}{*}{ educ } & $0.0195 * * *$ & $0.0193 * * *$ & $0.0188^{* * *}$ \\
\hline & $(0.000785)$ & $(0.000824)$ & $(0.00261)$ \\
\hline \multirow[t]{2}{*}{ religiosity } & $0.0178^{* * *}$ & $0.0203 * * *$ & -0.000219 \\
\hline & $(0.00435)$ & $(0.00451)$ & $(0.0160)$ \\
\hline \multirow[t]{2}{*}{ health } & $0.0335 * * *$ & $0.0328 * * *$ & $0.0424 * * *$ \\
\hline & $(0.00439)$ & $(0.00456)$ & $(0.0159)$ \\
\hline \multirow[t]{2}{*}{ urban } & $0.0191 * * *$ & $0.0138 * *$ & $0.0653 * * *$ \\
\hline & $(0.00624)$ & $(0.00650)$ & $(0.0217)$ \\
\hline Observations & 24,443 & 22,125 & 2,318 \\
\hline
\end{tabular}

Robust standard errors in parentheses $* * * \mathrm{p}<0.01, * * \mathrm{p}<0.05, * \mathrm{p}<0.1$

Table A9. Marginal Effect Estimation: Determinants of Subjective Poverty Five Years Ago

\begin{tabular}{|c|c|c|c|}
\hline & (All Sample) & (Muslim Sample) & (Non-Muslim Sample) \\
\hline Variables & $\begin{array}{c}\text { Dummysubjective } \\
\text { poverty_5ago } \\
\text { (marginal effect) dydx }\end{array}$ & $\begin{array}{c}\text { Dummysubjective } \\
\text { poverty_5ago } \\
\text { (marginal effect) dydx }\end{array}$ & $\begin{array}{c}\text { Dummysubjective } \\
\text { poverty_5ago } \\
\text { (marginal effect) dydx }\end{array}$ \\
\hline Inexpcharity & $\begin{array}{c}0.00881 * * * \\
(0.00194)\end{array}$ & $\begin{array}{c}0.00969 * * * \\
(0.00209)\end{array}$ & $\begin{array}{c}0.00393 \\
(0.00528)\end{array}$ \\
\hline lnincomepercapita & $\begin{array}{l}0.00340 * \\
(0.00201)\end{array}$ & $\begin{array}{c}0.00264 \\
(0.00212)\end{array}$ & $\begin{array}{c}0.00807 \\
(0.00617)\end{array}$ \\
\hline married & $\begin{array}{c}-0.0281 * * * \\
(0.00682)\end{array}$ & $\begin{array}{c}-0.0265 * * * \\
(0.00720)\end{array}$ & $\begin{array}{l}-0.0331 \\
(0.0212)\end{array}$ \\
\hline religion & $\begin{array}{c}0.0363 * * * \\
(0.00785)\end{array}$ & & \\
\hline ethnic & $\begin{array}{c}-0.0148 * * * \\
(0.00498)\end{array}$ & $\begin{array}{c}-0.0168 * * * \\
(0.00517)\end{array}$ & $\begin{array}{l}0.00892 \\
(0.0220)\end{array}$ \\
\hline male & $\begin{array}{c}-0.0319 * * * \\
(0.00490)\end{array}$ & $\begin{array}{c}-0.0300 * * * \\
(0.00518)\end{array}$ & $\begin{array}{c}-0.0454 * * * \\
(0.0152)\end{array}$ \\
\hline age & $\begin{array}{c}-0.00945 * * * \\
(0.000964)\end{array}$ & $\begin{array}{c}-0.00976 * * * \\
(0.00102)\end{array}$ & $\begin{array}{c}-0.00783 * * * \\
(0.00290)\end{array}$ \\
\hline agesquared & $\begin{array}{c}0.000133 * * * \\
(1.11 \mathrm{e}-05)\end{array}$ & $\begin{array}{c}0.000138 * * * \\
(1.18 \mathrm{e}-05)\end{array}$ & $\begin{array}{c}0.000101 * * * \\
(3.28 \mathrm{e}-05)\end{array}$ \\
\hline educ & $\begin{array}{c}0.00749 * * * \\
(0.000696)\end{array}$ & $\begin{array}{c}0.00770 * * * \\
(0.000737)\end{array}$ & $\begin{array}{c}0.00503 * * \\
(0.00213)\end{array}$ \\
\hline religiosity & $\begin{array}{c}0.00249 \\
(0.00375)\end{array}$ & $\begin{array}{c}0.00398 \\
(0.00396)\end{array}$ & $\begin{array}{l}-0.0126 \\
(0.0118)\end{array}$ \\
\hline health & $\begin{array}{l}0.0103 * * * \\
(0.00388)\end{array}$ & $\begin{array}{l}0.00797 * \\
(0.00407)\end{array}$ & $\begin{array}{c}0.0308 * * \\
(0.0129)\end{array}$ \\
\hline urban & $\begin{array}{c}0.0162 * * * \\
(0.00528)\end{array}$ & $\begin{array}{c}0.0145 * * * \\
(0.00558)\end{array}$ & $\begin{array}{c}0.0279 * \\
(0.0166)\end{array}$ \\
\hline Observations & 25,657 & 23,184 & 2,473 \\
\hline
\end{tabular}

Robust standard errors in parentheses $* * * \mathrm{p}<0.01, * * \mathrm{p}<0.05, * \mathrm{p}<0.1$ 
Table A10. Marginal Effect Estimation: Determinants of Life Happiness

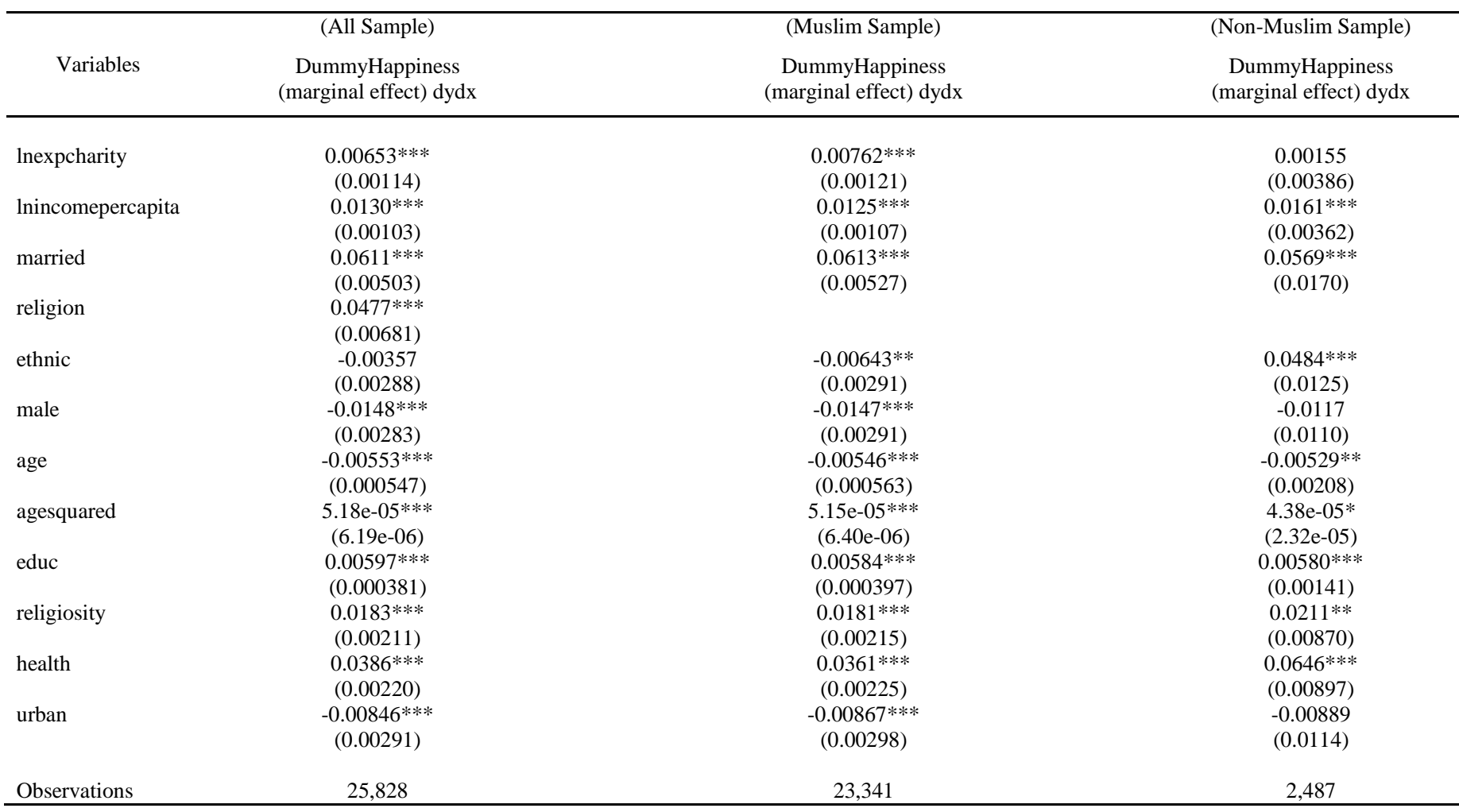

Robust standard errors in parentheses

$* * * \mathrm{p}<0.01, * * \mathrm{p}<0.05, * \mathrm{p}<0.1$

A11. Marginal Effect Estimation: Determinants of Life Happiness

\begin{tabular}{|c|c|c|c|}
\hline & (All Sample) & (Muslim Sample) & (Non-Muslim Sample) \\
\hline Variables & $\begin{array}{c}\text { Dummy } \\
\text { lifesatisfaction } \\
\text { (marginal effect) dydx }\end{array}$ & $\begin{array}{c}\text { Dummy } \\
\text { lifesatisfaction } \\
\text { (marginal effect) dydx }\end{array}$ & $\begin{array}{c}\text { Dummy } \\
\text { lifesatisfaction } \\
\text { (marginal effect) dydx }\end{array}$ \\
\hline Inexpcharity & $\begin{array}{c}0.0230 * * * \\
(0.00253)\end{array}$ & $\begin{array}{c}0.0263 * * * \\
(0.00273)\end{array}$ & $\begin{array}{c}0.00784 \\
(0.00709)\end{array}$ \\
\hline Inincomepercapita & $\begin{array}{l}0.0227 * * * \\
(0.00265)\end{array}$ & $\begin{array}{l}0.0234 * * * \\
(0.00281)\end{array}$ & $\begin{array}{c}0.0140 * \\
(0.00790)\end{array}$ \\
\hline married & $\begin{array}{c}0.0422 * * * \\
(0.00867)\end{array}$ & $\begin{array}{c}0.0403 * * * \\
(0.00915)\end{array}$ & $\begin{array}{c}0.0680 * * \\
(0.0269)\end{array}$ \\
\hline religion & $\begin{array}{c}0.102 * * * \\
(0.0107)\end{array}$ & & \\
\hline ethnic & $\begin{array}{l}-0.00984 \\
(0.00651)\end{array}$ & $\begin{array}{c}-0.0164 * * \\
(0.00671)\end{array}$ & $\begin{array}{c}0.0787 * * * \\
(0.0299)\end{array}$ \\
\hline male & $\begin{array}{c}-0.0449 * * * \\
(0.00636)\end{array}$ & $\begin{array}{c}-0.0435 * * * \\
(0.00671)\end{array}$ & $\begin{array}{c}-0.0538 * * * \\
(0.0201)\end{array}$ \\
\hline age & $\begin{array}{c}-0.0148 * * * \\
(0.00128)\end{array}$ & $\begin{array}{c}-0.0141 * * * \\
(0.00136)\end{array}$ & $\begin{array}{c}-0.0209 * * * \\
(0.00401)\end{array}$ \\
\hline agesquared & $\begin{array}{c}0.000150 * * * \\
(1.50 \mathrm{e}-05)\end{array}$ & $\begin{array}{c}0.000143 * * * \\
(1.59 \mathrm{e}-05)\end{array}$ & $\begin{array}{c}0.000210 * * * \\
(4.58 \mathrm{e}-05)\end{array}$ \\
\hline educ & $\begin{array}{l}0.00183 * * \\
(0.000882)\end{array}$ & $\begin{array}{c}0.00130 \\
(0.000936)\end{array}$ & $\begin{array}{c}0.00381 \\
(0.00271)\end{array}$ \\
\hline religiosity & $\begin{array}{l}0.112 * * * \\
(0.00492)\end{array}$ & $\begin{array}{l}0.114 * * * \\
(0.00516)\end{array}$ & $\begin{array}{l}0.107 * * * \\
(0.0164)\end{array}$ \\
\hline health & $\begin{array}{l}0.0982 * * * \\
(0.00501)\end{array}$ & $\begin{array}{l}0.0962 * * * \\
(0.00525)\end{array}$ & $\begin{array}{c}0.119 * * * \\
(0.0167)\end{array}$ \\
\hline urban & $\begin{array}{c}0.0238 * * * \\
(0.00687)\end{array}$ & $\begin{array}{c}0.0235 * * * \\
(0.00724)\end{array}$ & $\begin{array}{c}0.0167 \\
(0.0219)\end{array}$ \\
\hline Observations & 25,828 & 23,341 & 2,487 \\
\hline
\end{tabular}

Robust standard errors in parentheses

$* * * \mathrm{p}<0.01, * * \mathrm{p}<0.05, * \mathrm{p}<0.1$ 